\title{
Ludic Adaptation: Can We Babyfy, Chibify, Bambify, or Cherubify a Literary Text for Younger Audiences?
}

\author{
SF. Luthfie Arguby Purnomo ${ }^{a}$ \\ theluthfie@gmail.com \\ State Islamic Institute of Surakarta, Indonesia \\ Lilik Untari \\ nazala.suha@gmail.com \\ State Islamic Institute of Surakarta, Indonesia \\ SF. Lukfianka Sanjaya Purnama \\ iaftersmile@gmail.com \\ State Islamic Institute of Surakarta, Indonesia \\ Nur Asiyah \\ assyong2@gmail.com \\ State Islamic Institute of Surakarta, Indonesia \\ Robith Khoiril Umam \\ robith.umam11@gmail.com \\ State Islamic Institute of Surakarta, Indonesia \\ Yustin Sartika \\ yustinsartika@gmail.com \\ State Islamic Institute of Surakarta, Indonesia \\ Novianni Anggraini \\ beinghappymom@gmail.com \\ State Islamic Institute of Surakarta, Indonesia \\ Elen Inderasari \\ inderasari85iain@gmail.com \\ State Islamic Institute of Surakarta, Indonesia
}

\begin{abstract}
Studies on adaptation for younger audiences tend to mull over around the film adaptation of children classics. Adaptation of textual, visual, and operative elements for younger audiences in the context of literary texts with ergodicity like apps, comics, animation films, and games is understudied. This case study based descriptive qualitative study aims at exploring and investigating the phenomenon and how this adaptation is exercised. This study employs Siddharthan's text simplification, Genette's hypertextuality, Nikolajeva's Barthesian proairetic decoding for younger audiences, and Huizinga's play-function and play-mood to address the language aspects of ludic adaptation, Aarseth's ergodic literature and Sander's adaptation to address the literary aspects, and Rajewsky's intermediality to address the medial aspects. Drawing upon the theories and employing Spradleyan analysis, we argue that adaptation for younger audiences is best termed ludic adaptation, an adaptation aimed at establishing a playful communication involving textual, visual, and operative adjustments for younger audiences through transmodalization, transstylization, and transformation of the source texts. In adapting the apps, comics, animation films, and games into their simplified versions, the adapters employ what we call as babyfication, chibification, bambification, and cherubification. Scholars of language and literary studies might apply ludic adaptation to reveal how adaptation
\end{abstract}

${ }^{a}$ Main \& corresponding author 
for younger audiences is carried out. App, comic, animation film, and game adaptation practitioners might employ ludic adaptation as a guideline in their process of adapting these literary texts.

Keywords: adaptation; ludic; younger audiences; hypertextuality; text simplification

\section{INTRODUCTION}

Text simplification is the core focus of adaptation for younger audiences. The purpose of text simplification is to generate what Nikolajeva (2010) calls as proairetic decoding, a Barthesian decoding with an emphasis over nonbiased interpretation. To produce a proairetic decoding, text simplification, as suggested by Siddharthan (2014), has to address conceptual simplification, elaborative modification, and text summarization. These three elements of simplification are not only intended for textual simplification but also visual and operative simplifications. Together they form an adaptation specifically intended for younger audiences.

Text simplification refers to the act of reducing the complexity in comprehending the text through lexical, syntactical, and semantic modifications while preserving the source information and meaning (De Belder \& Moens, 2010; Siddharthan, 2006, 2014). Since the focus of text simplification is easy reading, image inclusion might be considered also as a method of simplification (Yaneva, 2015). Thus, modifications not only circumnavigate around lingual elements but also non-lingual elements. Through this text simplification, inexperienced readers, non-native readers, and younger readers are expected to comprehend the core message of the text without detaching themselves from the reading experiences that the text attempts to convey. In regard to younger audiences, text simplification leaves an interesting phenomenon on lingual and non-lingual aspects. Genette (1997) addresses this phenomenon as trimming or pruning, which is an act of excisioning unsuitable expressions or abridged transformation through simplification intended for an easy reading for younger audiences. This phenomenon evolves not only for a conventional paper-based text but also appearing on digital texts. YouTube Kids, for instance, has its lingual and operative aspects simplified. These textual and operative simplifications refer to interface transformation, which is designed to generate a light nuance deemed to be appropriate for children to consume. This simplification, which is exercised through the combination of trimming and expurgation, results in a derived text which Genette (1997) calls as hypertext. These textual and visual 'simplifications' are adjustments in the forms of transstylization and transmodalization, shifts on style and mode of presentation (Genette, 1997). In the context of YouTube Kids, the transstylization and transmodalization serve to incite a playful communication. Playful communication, as indicated by Mäyrä (2012), is related to playful traits, humor, play, and gaming, which influence tones and characters in social contexts. Square Enix's World of Final Fantasy, for example, packs a lot of characters from the mothership titles of Final Fantasy franchise from the first to the thirteenth installment. Since the game is intended for younger audiences, the game employs diminutives in many parts of the game especially the game's monsters. Adamantoise, for instance, is down toned into Minimantoise, Behemoth into Babyhemoth, and King Bomb into Bombino. The diminutive affixation of mini-, baby-, and -bino to derive a new onomastic word is accompanied by super deformed visualization to adjust the game with younger audiences. We argue that this phenomenon is better dubbed ludic adaptation.

Ludic adaptation is the gap left by previous studies that discuss adaptation. To prove that ludic adaptation is existent, we attempt to explore and investigate adaptation texts which target younger audiences. The literary texts which we used to indicate the presence of ludic adaptation have to possess ergodicity. Ergodic texts, based on Aarseth (1997), refer to literary texts which emphasize on how the readers access the texts. Apps are accessed through clicking, 
comics through panel reading, animation films through screen reading, and games through button smashing. Clicking, panel reading, screen reading, and button smashing are not found from conventional literary texts like novel which demands the readers to move the eyes from paragraph to paragraph. The purpose of employing ergodic texts is to reveal whether the way to access the texts is simplified when the texts are adapted for younger audiences. These texts were analyzed by implementing the theories of text simplification by Siddharthan (2014), hypertextuality by Genette (1997), Barthesian proairetic decoding for younger audiences by Nikolajeva (2010), and play-function and play-mood by Huizinga (2014) to address the language aspects of ludic adaptation, ergodic literature by Aarseth (1997) and adaptation by Sanders (2005) to address the literary aspects, and intermediality by Rajewsky (2011) to address the medial aspects.

\section{LITERATURE REVIEW}

The phrase 'literary text' here, as mentioned on the introduction section, refers to ergodic text. The readers, as implied by Aarseth (1997), are required to concern on the way to access the texts to capture the meaning the texts attempt to convey. Ergodic texts are different from conventional literary texts like novel which do not address the importance of text accessibility in grasping the meaning of the text. The primary feature of ergodic text is the significance of operative elements. Clicking, tapping, swiping, panel reading, screen reading, and button smashing are the examples of operative elements and these elements are a significant part in literary texts with ergodicity. The concern on this ergodicity is what makes ludic adaptation different from the other adaptation targeted for younger audiences. Thus, when ergodic texts are adapted, a process of transmodalization, transstylization, and transformation of the text takes place. Transmodalization deals with adjustment on functions, transstylization with adjustment on the content, and transformation with intertextual relationship adjustment with the source or related texts (Genette, 1997). Since the target audiences are younger audiences, text simplification is the drive of these three processes of adaptation.

Textual simplification, as suggested by Siddharthan (2014), encompasses conceptual simplification, elaborative modification, and text summarization. The first refers to content simplification, the second to the use of redundancy and explicitness to emphasize key points, and the third to the omission of peripheral or inappropriate expressions. These three types of text simplification operate in complementarity with visual and operative elements. Content simplification, in the context of younger audiences, demands the adapters to adjust the source contents with the audiences. Here the adapters perform what Genette (1997) calls as trimming or pruning on the story or narrative. In performing this adjustment, the core message or narrative of the source text is preserved to ensure that the transformation still preserves the intertextual relationship between the source text and the adaptation. Trimming and pruning are also implemented on the literary text with ergodicity if the target media is visual and operative in its mediality. The result of this content adjustment to younger audiences indicates that transmodalization and transstylization have been performed in accordance to the characteristics of the target audiences.

Trimming or pruning exercised on the story is not necessarily related to shortening the textual expressions of a literary text. Elaborative modification, which tends to add more expressions to provide a significant detail to secure a comprehensive digest by younger audiences, denotes that simplified comprehension from the audiences is an important aspect of text simplification. This elaborative modification is delivered through explicating an expression or making an expression sound redundant (Siddharthan, 2014). Expression explication is exercised in a form of proairetic decoding. This decoding is adapted from Barthesian codes by Nikolajeva (2010) to refer to what is read is what is meant. Proairetic 
decoding facilitates the necessity for an easy reading for younger audiences. Through explication, comprehension over the text might be assured but it discloses the problems of verbosity. Purnomo et al. (2020) suggests that verbosity is required to be checked through what is called amplicity level, which indicates whether a text is verbose or not. On the other hand, redundancy facilitates the playful or ludic nature of younger audiences. This nature is expressed through redundancy, which breaks the rules of lingual expressions to generate a comedic nuance. This intended use of redundancy is the realization of what Huizinga (2014) calls as play-mood and play-function which strengthens the position of younger audiences as homo ludens. One of the ways to express redundancy to trigger a comedic nuance is through word play. García Berrio (2016) addresses that the use of word play is a form of catachresis which functions as a surprise element for the readers.

To facilitate elaborative modification, adapters are required to negotiate between the content of the text and how the content is textually delivered. Text summarization is implemented to do so with concerns on mediality. Particular media has restrictions on how text is displayed and thus influencing which parts of the text are kept, which parts are omitted, and which parts are substituted. Text summarization, which is exercised due to these space related restrictions, might shift the identity of a text or what Petrucci (2012) suggests as character equivalence. Another problem which might arise is the status of the text. That a text summarized is a text of its own or a text which is intertextually linked to the source text is the problem. Treating a summarized text as the first indicates that the text neglects the existence of the source. This negligence indicates that the text refuses the status of being an adaptation. On the other hand, treating a summarized text as the second indicates that the summarized text is what Genette (1997) calls as paratext. Treating a summarized text as a paratext points out that transmodalization, transstylization, and transformation are exercised to fit the target audiences.

\section{METHOD}

This study is descriptive qualitative in design. The data of this study are in the forms of textual, visual, and operative elements as seen from the adaptations and their sources. The data were purposively taken from apps, comics, animation films, and games. The following table shows the sources of data from which the data were used to indicate the cases of ludic adaptation. The following titles were ergodic texts which had their adaptation for younger audiences. The use of ludic markers comprising of diminutive markers like baby, kids, and junior, comedic markers like go!, wan!, and oh!, and operative markers like pocket, mini mix, and stories was employed as a guideline to indicate whether an ergodic literary text was an adaptation or not.

TABLE 1. Sources of Data

\begin{tabular}{|c|c|c|c|c|c|c|c|}
\hline \multicolumn{2}{|c|}{ Apps } & \multicolumn{2}{|c|}{ Comics } & \multicolumn{2}{|c|}{ Animation Films } & \multicolumn{2}{|c|}{ Games } \\
\hline Source & Adaptation & Source & Adaptation & Source & Adaptation & Source & Adaptation \\
\hline YouTube & $\begin{array}{c}\text { YouTube } \\
\text { Kids }\end{array}$ & Naruto & $\begin{array}{l}\text { Rock Lee's } \\
\text { Springtime of } \\
\text { Youth Full- } \\
\text { Power Ninja } \\
\text { Chronicles }\end{array}$ & Looney Tunes & $\begin{array}{c}\text { Baby Looney } \\
\text { Tunes }\end{array}$ & $\begin{array}{c}\text { Final Fantasy } \\
\text { XV }\end{array}$ & $\begin{array}{c}\text { Final } \\
\text { Fantasy XV } \\
\text { Pocket } \\
\text { Edition }\end{array}$ \\
\hline PBS & PBS Kids & Naruto & $\begin{array}{l}\text { Naruto: Chibi } \\
\text { Sasuke's } \\
\text { Sharingan } \\
\text { Legend }\end{array}$ & $\begin{array}{c}\text { Overlord } \\
\text { Konosuba } \\
\text { Re:Zero-Starting } \\
\text { Life in Another } \\
\text { World } \\
\text { The Saga of } \\
\text { Tanya the Evil } \\
\text { (light novels) }\end{array}$ & Isekai Quartet & $\begin{array}{c}\text { Street Fighter } \\
\text { series } \\
\text { Darkstalkers } \\
\text { series } \\
\text { Red Earth }\end{array}$ & $\begin{array}{c}\text { Super Gem } \\
\text { Mini Mix/ } \\
\text { Pocket } \\
\text { Fighter }\end{array}$ \\
\hline
\end{tabular}




\begin{tabular}{|c|c|c|c|c|c|c|c|}
\hline $\begin{array}{c}\text { Nickelodeo } \\
\mathrm{n}\end{array}$ & Nick Jr. & Fairy Tail & $\begin{array}{l}\text { Fairy Tail S: } \\
\text { Tales from } \\
\text { Fairy Tail }\end{array}$ & $\begin{array}{c}\text { Tom and Jerry } \\
\text { series }\end{array}$ & $\begin{array}{c}\text { Tom and Jerry } \\
\text { Kids series }\end{array}$ & Monster Hunter & $\begin{array}{c}\text { Monster } \\
\text { Hunter } \\
\text { Stories }\end{array}$ \\
\hline Hulu & Hulu Kids & $\begin{array}{l}\text { Overlord } \\
\text { (light novel/ } \\
\text { anime) }\end{array}$ & $\begin{array}{c}\text { Overlord: the } \\
\text { Undead King } \\
\text { Oh! }\end{array}$ & $\begin{array}{l}\text { Teen Titans } \\
\text { (comic/film) }\end{array}$ & $\begin{array}{l}\text { Teen Titans } \\
\text { Go! }\end{array}$ & $\begin{array}{l}\text { Final Fantasy } \\
\text { I-XIII }\end{array}$ & $\begin{array}{l}\text { World of } \\
\text { Final } \\
\text { Fantasy }\end{array}$ \\
\hline Disney & $\begin{array}{l}\text { Disney } \\
\text { Junior }\end{array}$ & $\begin{array}{c}\text { Bungou Stray } \\
\text { Dogs } \\
\text { (comic/ } \\
\text { anime) }\end{array}$ & $\begin{array}{l}\text { Bungou Stray } \\
\text { Dogs Wan! }\end{array}$ & Scooby-Doo & $\begin{array}{l}\text { A Pup Named } \\
\text { Scooby-Doo }\end{array}$ & $\begin{array}{c}\text { Final Fantasy } \\
\text { I-XIII }\end{array}$ & $\begin{array}{c}\text { Theatrhyth } \\
\text { m } \\
\text { Final } \\
\text { Fantasy }\end{array}$ \\
\hline \multirow[t]{4}{*}{$\mathrm{HBO}$} & HBO Kids & $\begin{array}{l}\text { Justice League } \\
\text { (comic/ } \\
\text { cartoon) } \\
\text { Scribblenauts } \\
\text { (game) }\end{array}$ & $\begin{array}{l}\text { Scribblenauts } \\
\text { Unmasked: a } \\
\text { Crisis of } \\
\text { Imagination }\end{array}$ & $\begin{array}{r}\text { Attack on Titan } \\
\text { (manga/anime) }\end{array}$ & $\begin{array}{l}\text { Attack on } \\
\text { Titan: Junior } \\
\text { High } \\
\text { (manga/ } \\
\text { anime) }\end{array}$ & & \\
\hline & & Bleach & $\begin{array}{l}\text { Let's Start } \\
\text { Koma-Bleach }\end{array}$ & $\begin{array}{c}\text { Sword Art } \\
\text { Online } \\
\text { (light } \\
\text { novel/anime) }\end{array}$ & $\begin{array}{l}\text { Sword Art } \\
\text { Offline } \\
\text { (bundled) }\end{array}$ & & \\
\hline & & Donald Duck & $\begin{array}{l}\text { Young Donald } \\
\text { Duck }\end{array}$ & The Flintstones & $\begin{array}{l}\text { The } \\
\text { Flintstones } \\
\text { Kids }\end{array}$ & & \\
\hline & & Disney & Disney Babies & Naruto & $\begin{array}{l}\text { Naruto: Rock } \\
\text { Lee and His } \\
\text { Ninja Pals }\end{array}$ & & \\
\hline
\end{tabular}

Technique of analysis from Spradley (2016) was applied in this study. Four phases of analysis namely domain, taxonomy, componential, and finding cultural theme were taken to complete the analysis. First, in domain analysis, Genette's transmodalization theory was applied to reveal whether the adaptation of the ergodic texts was designed for younger audiences or not. After revealing the target audiences, taxonomy analysis took place. Here Genette's transstylization was applied with the support from Siddharthan's text simplification, Nikolajeva's Barthesian proairetic decoding, and Huizinga's play-mood and play function. Language aspects of the adaptations were analyzed to reveal whether the adaptations employed conceptual simplification, elaborative modification, or text summarization. Adaptations intended for younger audiences tend to employ the three of them with elaborative modification on explication of expressions. On the other hand, adaptations designed in a younger version of the characters tend to employ the first and the second on redundancy making. Departing from the findings, the next step was to apply Genette's transformation supported by Rajewsky's mediality theory to indicate whether the adaptations still preserve an intertextual relationship with the source text or not. The next step was componential analysis. Here the findings from domain and taxonomy analysis were presented in a table to indicate their relationship. This relationship would point out the categorization of ludic adaptation. The last was finding cultural theme. In this phase, differences and similarities of each ludic adaptation type were analyzed to signify the textual, visual, operative elements of each type.

\section{FINDINGS}

The findings indicate that the adaptation for younger audiences exercised by the selected ergodic texts in the form of apps, comics, films, and games is best termed ludic adaptation since the adaptation has a specific pattern which differentiates it from adaptation in general. The pattern is indicated by five characteristics. First, the adaptation shares similarities in their childlike visualization with differences on the depiction of characters namely super deformed and younger version visualization. Second, the adaptation tends to lean over text simplification and beautification to signify the friendliness of the products for younger audiences. Third, the adaptation occurring on apps and games tends to have a simple operative instruction and interface. Fourth, the narratives of the adaptation tend to undergo reduction. Fifth, the 
communication the adaptation attempts to chanel emphasizes the play-function of communication and relies on labile and merry play-mood. From these five criteria namely super deformed and younger version visualization, text simplification and beautification, simple operative instruction and interface, narrative reduction, and playful communication, we constructed ludic adaptation. We classify ludic adaptation into babyfication, chibification, bambification, and cherubification. The following example might illustrate better what ludic adaptation is.

In babyfication, for instance, the adapters tend to add diminutives on the titles like baby, kid, junior, and young to inform that the target audiences of the texts are younger audiences. This textual modification is further elaborated in the content. The textual content of the adapted text tends to employ conceptual simplification, elaborative modification on explication of expressions, and text summarization. The following example from Fraidy Cat episode of Tom and Jerry Kids might help illustrate the statement.

Fraidy Cat was the adaptation of the source Tom and Jerry episode by the the title Timid Tabby. When this episode was babyfied, Timid Tabby was not kept as the title. The episode was entitled Fraidy Cat, which was actually used for a different episode in the source Tom and Jerry. The title uses diminutive marker Fraidy to indicate that the adaptation is intended for younger audiences. The use of diminutive in fraidy also strengthens the childlike nuance of the series and the status of Tom's cousin as a 'scaredy' cat proairetically. To strengthen the impression that Fraidy Cat is for younger audiences, Tom's cousin was altered from George to Tim. The use of Tim, if sided with Tom, creates a rhyming effect. These changes were exercised to indicate that the adaptation version was conceptually modified to adjust the film to the younger audiences.

Fraidy Cat in Tom and Jerry Kids also heavily uses elaborative modification in the form of expression explication. Tom's cousin was more talkative than he was on the source film since the babyfied film has to explain in detail to the younger audiences what is actually going on. In the source film, the emphasis was given on the slapstick actions between Tom, Jerry, and his cousin, which have become the trademark of the series. In the babyfied version, Tom's cousin acted more as a storyteller for the story. For instance, when Tom taught his cousin about the history of cat that had never been defeated by a mouse in a teacher and student fashion, it was his cousin who spoke. He attempted to tell the younger audiences what Tom was trying to explain from the perspective of a student. The following table might help clarify this statement:

TABLE 2. Visual Verbalization in Fraidy Cat

\begin{tabular}{lll}
\hline Key words & Visual & Verbalization \\
\hline Cat, big, mouse, small & $\begin{array}{l}\text { Tom shows Tim the picture of a } \\
\text { big cat and a small mouse }\end{array}$ & $\begin{array}{l}\text { 'I think I got it! I think I got it! That's a mouse and } \\
\text { that's a cat like me. A cat's ten times bigger than a } \\
\text { mouse }\end{array}$ \\
Cat, stronger & $\begin{array}{l}\text { Tom shows Tim the picture of a } \\
\text { big cat with muscles and an } \\
\text { astonished mouse } \\
\text { Tom shows Tim the picture of a } \\
\text { big cat chasing a small mouse }\end{array}$ & $\begin{array}{l}\text { 'A cat is ten times stronger and more ferocious than a } \\
\text { mouse.' }\end{array}$ \\
$\begin{array}{l}\text { Cat, chase, mouse, run } \\
\text { away }\end{array}$ & \begin{tabular}{l} 
cat. Any mouse would run away from a ferocious \\
\hline
\end{tabular}
\end{tabular}

As seen from the table, explication of the visuals is intended to deliver the key words to the younger audiences in order to make them comprehend the story better. To even support this story comprehension attempt, Tim was also given more dialogue in soliloquy to indicate his characterization and character development. This story explication through verbalization points out that elaborative modification is in use.

Though the story is explicated to fit the younger audiences, narratively an expression like 'ferocious' which tends to be a harsh word for younger audiences is preserved to point out 
that Tim attempts to build his confidence and to hide his fear by exaggerating the nature of a cat. These attempts are mostly seen from his soliloquy. On one of his soliloquies, he says, "So I missed the mouse but I was trying. I promise it will never get rid of me until I get rid of that puny little mouse. A big one would be something else but who's afraid? There are no big mice." This soliloquy attempts to narratively connect Tim's attempts to build confidence while hiding his fear and the narrative part where Tom teaches Tim about cat and mouse.

To even ease the younger audiences in comprehending the story, text summarization was also applied. The summarization was visually applied by preserving the core messages of the rivalry between Tom and Jerry while altering actions deemed to be inappropriate for younger audiences to watch. In the opening scene of Timid Tabby, the episode describes Tom's cousin's musophobia through written expression via a letter to Tom and dialogues. When the episode was babyfied, this description was deleted and replaced by the visualization of musophobia. The following table helps to comprehend how the summarization is carried out:

TABLE 3. Musophobia Summarization in the Opening Scenes of Timid Tabby and Fraidy Cat

\begin{tabular}{llll}
\hline Timid Tabby & Fraidy Cat & Timid Tabby & Fraidy Cat \\
\hline $\begin{array}{l}\text { Written Expressions } \\
\begin{array}{l}\text { I do hope there are no } \\
\text { mice. You know how they }\end{array}\end{array}$ & $\begin{array}{l}\text { Written Expressions } \\
\text { No written expression to } \\
\text { indicate musophobia }\end{array}$ & $\begin{array}{l}\text { Verbal Expressions } \\
\text { Are you sure there aren't } \\
\text { mice? }\end{array}$ & $\begin{array}{l}\text { Verbal Expressions } \\
\text { No verbal expression to } \\
\text { indicate musophobia }\end{array}$ \\
& & $\begin{array}{l}\text { I wish I was brave like } \\
\text { other cats but I am not. I } \\
\text { guess I am just a scaredy } \\
\text { cat. }\end{array}$ & $\begin{array}{l}\text { No verbal expression to } \\
\text { indicate musophobia }\end{array}$ \\
& & & \\
\hline
\end{tabular}

As seen from the table, the opening scene in Timid Tabby is summarized into an action when adapted into Fraidy Cat. The use of action or visualization to replace written and verbal expressions is an attempt to inform the younger audiences that the episode will be all about musophobia in a simpler direct way.

\section{LUDIC ADAPTATION TAXONOMY}

We classify ludic adaptation into four types namely babyfication, chibification, bambification, and cherubification. We borrow the names from the already well-known popular terms on cartoon, anime, manga, games, and religion. In classifying the types, we lean over three structural criteria, as proposed by Genette (1997), namely transmodalization, transstylization, and transformation.

TABLE 4. Ludic Adaptation Type Classification

\begin{tabular}{|c|c|c|c|c|c|c|c|c|c|c|c|c|c|}
\hline & \multicolumn{2}{|c|}{ Transmodalization } & \multicolumn{3}{|c|}{ Transstylization } & \multicolumn{8}{|c|}{ Transformation } \\
\hline & \multirow{2}{*}{$\begin{array}{c}\text { Younger } \\
\text { Audiences }\end{array}$} & \multirow{2}{*}{$\begin{array}{l}\text { Younger } \\
\text { Versions }\end{array}$} & \multirow{2}{*}{$\begin{array}{c}\text { Textual } \\
\text { Adjustments }\end{array}$} & \multirow{2}{*}{$\begin{array}{c}\text { Visual } \\
\text { Adjustments }\end{array}$} & \multirow{2}{*}{$\begin{array}{c}\text { Operative } \\
\text { Adjustments }\end{array}$} & \multicolumn{3}{|c|}{ Reduction } & \multicolumn{3}{|c|}{ Mediality } & \multicolumn{2}{|c|}{ Play-Mood } \\
\hline & & & & & & Exc & Cos & Cod & Tra & Com & Ref & Lab & Mer \\
\hline Babyfication & Yes & Yes & Yes & Yes & Yes & Trim & $\begin{array}{l}\text { Yes/ } \\
\text { No }\end{array}$ & No & $\begin{array}{l}\text { Yes/ } \\
\text { No }\end{array}$ & $\begin{array}{l}\text { Yes/ } \\
\text { No }\end{array}$ & Imi & No & Yes \\
\hline Chibification & Yes & No & Yes/No & Yes & Yes/No & Prune & $\begin{array}{l}\text { Yes/ } \\
\text { No }\end{array}$ & No & $\begin{array}{l}\text { Yes/ } \\
\text { No }\end{array}$ & $\begin{array}{l}\text { Yes/ } \\
\text { No }\end{array}$ & Imi & Yes & No \\
\hline Bambification & Yes & Yes & Yes & Yes & Yes/No & Trim & $\begin{array}{l}\text { Yes/ } \\
\text { No }\end{array}$ & Yes & $\begin{array}{l}\text { Yes/ } \\
\text { No }\end{array}$ & $\begin{array}{l}\text { Yes/ } \\
\text { No }\end{array}$ & Evo & Yes & Yes \\
\hline Cherubification & Yes & No & Yes/No & Yes & Yes/No & Prune & $\begin{array}{l}\text { Yes/ } \\
\text { No }\end{array}$ & Yes & $\begin{array}{l}\text { Yes/ } \\
\text { No }\end{array}$ & $\begin{array}{l}\text { Yes/ } \\
\text { No }\end{array}$ & Evo & Yes & Yes \\
\hline
\end{tabular}

Exc: Excision Cos: Concision Cod: Condensation

Tra: Medial Transposition Com: Media Combination Ref: Intermedial Reference

Imi: Imitation Evo: Evocation Lab: Lability Mer: Merriness

Trim: Trimming Prune: Pruning 
To give a clear explanation on the characteristics of each type, as seen from table 4, each type will be described one by one in sections. The explanation of each type will be based on its distinctive characteristics.

\section{BABYFICATION}

Borrowing the term from popular reference for a transformation of something to appear babylike or childlike, babyfication refers to a ludic adaptation which adopts the younger version visualization of the original character. Besides visual adjustment, babyfication also adopts textual and operative adjustments to strengthen the image and impression that the adaptation serves younger audiences at their early age. The adjustments, just like other types of ludic adaptation, are exercised through reduction mostly in the forms of excision and expurgation, implying that concerns on simplicity and morality are the focus of the ludic adaptation. Excisions are exercised through trimming, signifying that embellishment to decorate the adaptation to have a child tone or nuance is the focus of excisions and expurgation.

Though adjustments are made, the narrative and mediality are preserved to mimic the source texts in a straight linear means, meaning that the adaptation employs the same narrative formula or theme as the source texts. Babyfied apps tend to faithfully follow the primary interface functions of the originals with differences on the adjustments and the embellishment to evoke a children friendly impression. The same cases are also found from babyfied films. Tom and Jerry Kids faithfully follows the cat mouse bittersweet relationship of Tom and Jerry. A Pup Named Scooby-Doo also faithfully follows the detective like mystery adventures of the source texts. A unique finding is seen from The Flintstones Kids, in which husband-wife relationships Fred, Wilma, Barney, and Betty have are transformed into friendship.

Textual adjustments in babyfication tend to be delivered through conceptual simplification, elaborative modification on explication of expressions, and text summarization. The implementation of these three types of text simplification are not only seen from the addition of kids, a pup, and junior on the title to embellish the nuance and tone of a kid's world, but also from the contents. The tone, besides being identical to colorfulness, is also pedagogically related. In Disney Babies Baby Donald Makes a Sandwich: a Book about Sequencing by Butt (1987), for instance, Baby Donald implies that he teaches the younger readers the steps of making a sandwich, to which the younger readers can practice. The same pedagogical values are also found from The Walt Disney Company's Disney Babies series like Disney Babies: Baby Goofy Catches a Fish: A Book about Rhyming Words by Hardy (1987), Disney Babies: Where's Baby Mickey's Red Ball: A Book about Colors by Hardy (1987), and Disney Babies: Good Night, Baby Donald: A Book about Counting by Hardy (1987). Each title is equipped with sub title explaining what lessons younger readers could learn from them. To adjust these pedagogical contents, Disney Babies is formatted in a board book, designed especially for kids for an easy reading.

The following example from Hanna and Barbera's The Flintstones and its babyfied version, Hanna and Barbera's The Flinstone Kids, might illustrate how the content is babyfied through conceptual simplification, elaborative modification on explication of expressions, and text summarization:

Meet the Flintstones

Flintstones.

Meet the Flintstones.

They're the modern stone age family.

From the town of Bedrock,

They're a page right out of history.

Let's ride with the family down the street.
The Flinstone Kids

Yabba dabba yabba dabba doo

We are the Flintstone kids

Yabba dabba yabba dabba doo

The Bedrock Flintstone kids

B-E-D-R-O-C-K

We're growing up in the bedrock way 
Through the courtesy of Fred's two feet. When you're with the Flintstones you'll have a yabba dabba doo time. A dabba doo time.

You'll have a gay old time.
Yabba dabba yabba dabba doo

We are the Flintstone Kids

Yabba dabba yabba dabba doo

The Bedrock's Flintstone kids

The theme song of The Flintstones is Meet the Flintstones. This title attempts to strengthen the family narrative of the film which revolves around familial and neighborhood matters. When The Flintstones was babyfied into The Flintstone Kids, the theme song was adjusted to younger viewers. The adjustments cover the title and the lyrics. The theme song is entitled The Flintstone Kids, which emphasizes the narrative of friendship. Though the lyrics of the babyfied version are textually and musically different, it still preserves a narrative connectedness with the source by mentioning the setting of place, Bedrock, and keeping Fred Flintstone's iconic catchphrase Yabba Dabba Doo. Besides keeping the narrative connectedness, the lyrics of The Flintstone Kids are also simplified. This simplification is seen from the use of repetitions in yabba dabba doo, we are the Flintstone kids, and Bedrock. Spelling act, which is identical to kids, is also employed to generate a child nuance as seen from $B-E-D-R-O-C-K$. These uses of repetitions and spelling acts indicate that conceptual simplification, elaborative modification on explication of expressions, and text summarization are implemented.

\section{CHIBIFICATION}

Chibification comes from the popular word chibi which means 'short' in Japanese (Kacsuk, 2018). This word is identical to Japanese manga and anime drawing technique. Chibification is different from babyfication in transmodalization with chibification emphasizing on younger audiences only. Since the emphasis is on younger audiences, the focus primarily lies on the visual transstylization. From these visual adjustments, chibification attempts to establish a comedic tone. To strengthen the comedic tone, textual aspects in the form of narration and dialogue are transstylized also in comedic tone. To generate this comedic tone, puns and slapsticks are commonly employed in chibification. In Taira's Rock Lee's Springtime of Youth Full-Power Ninja Chronicles and Naruto: Rock Lee and His Ninja Pals, the chibified version of Kishimoto's Naruto, for instance, the author parodies many of the original jutsu, a ninja skill, in a slapstick manner.

TABLE 5. Chibified Jutsu in Taira's Rock Lee's Springtime of Youth Full-Power Ninja Chronicles and Naruto: Rock Lee and His Ninja Pals

\begin{tabular}{|c|c|c|c|}
\hline Source Jutsu Names & Visualization & Chibified Jutsu Names & Visualization \\
\hline $\begin{array}{l}\text { Rasengan } \\
\text { (Spiraling Sphere) }\end{array}$ & $\begin{array}{l}\text { Naruto casts a spiraling } \\
\text { blue sphere and hits the } \\
\text { foes with it }\end{array}$ & $\begin{array}{l}\text { Rasenken } \\
\text { (Spiraling Power) }\end{array}$ & $\begin{array}{l}\text { Rock Lee imitates Naruto's } \\
\text { rasengan by throwing } \\
\text { himself into the air and turns } \\
\text { himself into wool like } \\
\text { spiraling ball }\end{array}$ \\
\hline $\begin{array}{l}\text { Konoha Senpu } \\
\text { (Konoha Whirlwind) }\end{array}$ & $\begin{array}{l}\text { Rock Lee delivers } \\
\text { whirlwind like fast kicks } \\
\text { toward his foes }\end{array}$ & $\begin{array}{l}\text { Mayuge Senpu } \\
\text { (Eyebrow Whirlwind) }\end{array}$ & $\begin{array}{l}\text { Rock Lee uses his iconic } \\
\text { thick eyebrows instead of his } \\
\text { feet }\end{array}$ \\
\hline $\begin{array}{l}\text { Hakkeshô Kaiten } \\
\text { (Eight Trigrams Palm } \\
\text { Revolving Heaven) }\end{array}$ & $\begin{array}{l}\text { Neji spins himself to } \\
\text { yield a wind barrier to } \\
\text { block any attacks }\end{array}$ & $\begin{array}{l}\text { Konoha Kaiten } \\
\text { (Konoha Revolving Heaven) }\end{array}$ & $\begin{array}{l}\text { Rock Lee imitates Neji by } \\
\text { spinning himself without } \\
\text { inducing any wind barrier }\end{array}$ \\
\hline
\end{tabular}

The three jutsu examples are just few of many other jutsu Rock Lee, the main character of the chibified manga, imitates. This imitation is aimed at generating comedy. The uses of word plays to induce a comedic tone on the jutsu's onomastic elements and the slapsticks on the jutsu visualization indicate that elaborative modification on redundancy making is 
implemented. In rasenken, for example, the similarity of rasen surprises Lee's friends since rasengan is the signature move of Naruto. It turns out that what Lee means from rasen (lit. spiral) is that Lee circles himself over and over in mid air. This concept of what-happens-isnot-what-is-expected with word play as the surprise element serves the parodic or comedic tone of the jutsu.

In chibification, excisions are not exercised through trimming but they tend to be exercised via pruning, implying that embellishment for decorative functions is not the focus but to simplify the narrative and fit it for comedic purposes. Square Enix's Final Fantasy XV Pocket Edition, Atsushi's Let's Start Koma Bleach, Taira's Naruto: Rock Lee and His Ninja Pals, Taira's Chibi Sasuke's Sharingan Legend, Mashima's Fairy Tail S: Tales from Fairy Tail, Maruyama and Satoshi's Overlord: The Undead King Oh!, and Neko's Bungou Stray Dogs Wan! fit this type of ludic adaptation. The pruning applied on these titles generates a direct intermedial reference to the source texts and thus knotting the narrative between the adaptations and the source texts.

In gaming context, as found from Square Enix's Final Fantasy XV: Pocket Edition, the trimming exercised on operative elements generates a different gaming experience. In the game, the battles are simplified, side quests which provide a deeper narrative involvement are deleted, and world exploration is limited. These trimming based transformations are done to fit the characteristics of mobile games which are designed for casual gamers, who have no time to play the games as what hardcore gamers do. Since games, as implied by Purnomo et al. $(2017 ; 2019)$, are basically diegetic and prosthetic, this ludic adaptation leads to the emergence of different gaming experience. To notify this difference on gaming experience, textually it has been indicated from the titles. Commonly chibified titles have additional comedic expressions like chibi, pocket, or small or a pun like wan, which means 'bark' in Japanese as found from Bungou Stray Dogs Wan! and oh, a pun of 'ou', 'king' in Japanese, stylized in an astonishing expression as found from Overlord: The Undead King Oh!. Though the word 'pocket' is not always identical to chibification, essentially it refers to chibified visualization. This case is seen from Capcom's Pocket Fighter. In mobile gaming context, the word 'pocket' has also been commonly used to indicate that the game is a mobile game. Besides Final Fantasy XV: Pocket Edition, the other examples are also found from Mojang Studios' Minecraft Pocket Edition. Thus, generally the word 'pocket' in gaming context might refer to chibified visualization, simplified game mechanics, and mobile games.

\section{BAMBIFICATION}

Bambification, derived from Italian word bambino which refers to both 'baby' and 'silly', shares similarities to babyfication in most of the criteria with differences primarily on intermedial reference. Babyfication employs imitative intermedial reference, meaning that the hypertext shares similar formula on narrative and operative elements. On the other hand, bambification employs evocative intermedial reference and condensed reduction on the narratives. Disney Babies series might fall into this category since babyfied characters from Disney are packed in titles which do not mention the name of a specific character e.g. Disney Babies at the Farm: a Book about Farm Words by Lakin (1990) and Disney Babies at the Big Circus: a Book of Opposites by Gould (1987). These titles are the examples of bambified adaptation since the characters are the younger versions of the source characters and the narratives are condensed through reference.

What is unique about Disney Babies is that the series are designed for an early childhood English language learning. Since the language learning is intended for early childhood, visual elements take a larger portion than the textual elements. Thus, it implies that the narrative of these pedagogical books relies on pictorial depictions. These depictions are not 
simply drawn to support the textual aspects of language learning but they have a referential purpose. The following examples from Disney Babies at the Big Circus: a Book of Opposites might illustrate the statement better:

TABLE 6. Intermedial References in Disney Babies at the Big Circus: a Book of Opposites

\begin{tabular}{|c|c|c|}
\hline Textual Lines & Intermedial References & Visual Evidences \\
\hline Disney Babies at the Big Circus & Mickey’s Circus (1936 film) & $\begin{array}{l}\text { Baby Mickey stands on a platform at the } \\
\text { center of the stage acting as the circus master } \\
\text { mimicking what the original Mickey does in } \\
\text { the film }\end{array}$ \\
\hline Baby Daisy sees the little elephant & Dumbo (1941 film) & As seen from the headscarves the elephants \\
\hline Baby Donald sees the big elephant & $\begin{array}{l}\text { Donald Duck's Circus (1971 } \\
\text { storybook) }\end{array}$ & $\begin{array}{l}\text { wore and their facial expressions, the } \\
\text { elephants baby Daisy and baby Donald see } \\
\text { bear resemblance to Dumbo and his mother, } \\
\text { Mrs. Jumbo. }\end{array}$ \\
\hline $\begin{array}{l}\text { The ball goes up } \\
\text { The ball goes down }\end{array}$ & Mickey’s Circus (1936 film) & $\begin{array}{l}\text { That the ball tricks are played by seals } \\
\text { resembles the same actions by the same } \\
\text { circus animals in the film }\end{array}$ \\
\hline
\end{tabular}

The presence of intermedial references in a pedagogical book points out that Disney attempts to preseve the narrative connectedness of all its literary products while at the same time ensuring that the pedagogical purpose of the book is not out of the track. In the perspectives of text simplification, the one sentence expression the book contains points out that Disney carefully selects the textual elements along with the visual elements to ensure that the intermedial references are transferred.

An intriguing case is found from Young Donald Duck by Artibani, Ambrosio, and Ferrari (2019). The comic narrates the silly adventure of the twelve years old Donald Duck in his school time at Jeremy Ratt Boarding School. There he meets many younger versions of Disney iconic characters like Mickey Mouse. The wrapping up of some characters from different titles makes this comic tend to adopt evocative intermedial reference to other comics and that makes Young Donald Duck tend to embrace bambification.

The problem with Young Donald Duck in regard to bambification is that there seems to be no apparent shift on the age rating. Young Donald Duck is intended for 9+ of age while the original Donald Duck, if seen from Ducktales series, is intended for 6+. This difference signifies that from the perspective of numeric age rating, Young Donald Duck is not intended for younger audiences but from the perspective of narratives, the Donald Duck in Young Donald Duck is the younger version of Donald Duck. In term of condensed narratives, Young Donald Duck, Ducktales, and Silly Symphony: The Wise Little Hen, where Donald Duck appears for the first time, share the same Disney world, where iconic Disney characters interact to each other, meaning that even the originals have a condensed narrative. In this case where condensed narratives are already present in the sources and the adaptations follow the same narrative formula, bambification and babyfication tend to overlap.

Another interesting finding is also found from Nakagawa's Attack on Titan: Junior High. This manga and anime adaptation indicates that the characters are the younger versions of the source characters but the visualization tends to be more of super deformed or chibi. This is seen from the idea that the titan, shown evocatively, is designed in chibi. This ludic adaptation also offers something intriguing in regard to titan motif and survival allusions of the original narratives. These allusions indicate that the adaptation might be classified into bambification if the allusions signify a condensation of narrative. Yet it might be a babyfied adaptation if the allusions indicate that narrative condensation is not apparent. 


\section{CHERUBIFICATION}

Cherubification, drawn upon Cherub, a chubby childlike angel with a pair of wings, has the same characteristics with chibification yet different on the reduction and intermedial reference. Cherubification adopts chibi drawing but presenting the narratives and mediality in condensed and referential manners. Square Enix's World of Final Fantasy, which adopts some key figures from the first Final Fantasy to the thirteenth Final Fantasy, tends to be evocative in its intermedial references since the key figures act as a cameo in a brand new world where a novel narrative unfolds. The same case of cherubification also occurs in Square Enix's Theatrhythm Final Fantasy, a song rhythm matching game. The game adopts key figures from the mothership titles of Final Fantasy just like World of Final Fantasy with differences on the genres of the game. Due to the differences on genres, the textual, visual, and operative adjustments also experience an adaptation with simplification as the objective of the adjustments.

World of Final Fantasy displays a unique case in terms of its textuality in indicating that the game is intended for younger gamers. The game makes use of diminutive and augmentative comparison to narrate the intermedial references of the game and to emphasize the target players of the game. The following table helps to comprehend the comparison:

TABLE 7. Diminutive and Augmentative Comparison in World of Final Fantasy

\begin{tabular}{|c|c|c|c|c|}
\hline $\begin{array}{l}\text { Diminutive } \\
\text { (Mirage Names) }\end{array}$ & Diminutive Markers & $\begin{array}{l}\text { Augmentative } \\
\text { (Mirage Names) }\end{array}$ & $\begin{array}{l}\text { Augmentative } \\
\text { Markers }\end{array}$ & $\begin{array}{l}\text { Comparative } \\
\text { Markers }\end{array}$ \\
\hline Bablizz & Bab (babe) & Shiva & Myth & Referential \\
\hline Babyhemoth & Baby & Behemoth & Behemoth & Size \\
\hline Baby Paleberry & Baby & Paleberry King & King & Hierarchical \\
\hline Baby Tonberry & Baby & Tonberry King & King & Hierarchical \\
\hline Bombino & Bambino (pun) & King Bomb & King & Hierarchical \\
\hline Brothertaur & Brother & Minotaur & Myth & Referential \\
\hline Chocobo & None (visual) & Hyperion & Hyper & Size \\
\hline Chocobo & None (visual) & Mecha Chocobo & Mecha & Referential \\
\hline \multirow[t]{2}{*}{ Copper Gnome } & Copper & Mythril Giant & Mythril & Size \\
\hline & Gnome & & Giant & Referential \\
\hline Floating Eye & None (visual) & Ahriman & Myth & Referential \\
\hline Fritt & None (visual) & Ifrit & Myth & Referential \\
\hline Goblin & Myth & Red Captain & Captain & Hierarchical \\
\hline Goblin Guard & Myth & Princess Goblin & Princess & Hierarchical \\
\hline Imp & $\operatorname{Imp}$ & Diabolos & Myth & Referential \\
\hline Mimic & None (visual) & Mimic Queen & Queen & Hierarchical \\
\hline Mini Flan & Mini & Flan & None (visual) & Size \\
\hline Minimantoise & Mini & Adamantoise & Adamant & Size \\
\hline $\mathrm{Mu}$ & None (visual) & Reaver $\mathrm{Mu}$ & Myth & Referential \\
\hline Nightsqual & None (visual) & Mega Nightsqual & Mega & Size \\
\hline Quacho & None (visual) & Quacho Queen & Queen & Hierarchical \\
\hline Sea Snake & None (visual) & Leviathan & Myth & Referential \\
\hline Serafie & None (visual) & Diva Serafie & Diva & Hierarchical \\
\hline Sharqual & None (visual) & Mega Sharqual & Mega & Size \\
\hline Sylph & Myth & Siren & Myth & Referential \\
\hline Tama & Tama & Tamamohime & Hime & Hierarchical \\
\hline Unicorn & None (visual) & Odin & Myth & Referential \\
\hline Vampire & None (visual) & Vampire Prime & Prime & Hierarchical \\
\hline White Nakk & None (visual) & Fenrir & Myth & Referential \\
\hline Zapt & None (visual) & Ramuh & Myth & Referential \\
\hline
\end{tabular}

The use of diminutives and augmentatives for the names of the monsters, which are called Mirages in the game, is to strengthen the narratives and the intermedial references of the game. The game tells about a pair of siblings, Lann and Reynn, going for an adventure in a fantasy world of which the inhabitants are super deformed. Unlike the inhabitants, the siblings are much bigger than them. Their big size earns them the name 'jiants'. They can capture 
Mirages, breed them, and evolve them. Since the Mirage can evolve into a stronger or bigger monster, augmentatives are implemented to signify this shift of size and strength. This narrative is strengthened by the use of diminutives and augmentatives over their names. Diminutives and augmentatives are also used to preserve an intermedial reference to the mothership titles of the Final Fantasy series. That the comparative markers are dominated by referential markers indicates that to some extent the game attempts to synchronize itself intermedially with the original titles.

As seen from table 7, World of Final Fantasy not only employs size related diminutives which are commonly used e.g. baby, mini, and bambino but also diminutives which are identical to Role Playing Game (RPG) and monster breeding genres e.g. mythical references. The use of these diminutives implies that the game also attempts to preserve the unique identity of an RPG and monster breeding in a single genre. The same fusion of genres is also found from Capcom's Monster Hunter Stories, a cherubified adaptation of Monster Hunter franchise. The game adds the word stories to indicate that the game is not like its original title which heavily focuses on action and discards the storial element in role playing game fashion. This title, rated E+10 (everyone and not for under 10) by Entertainment Software Rating Board (ESRB), tends to adopt cherubification but it has different presentation of condensed reduction and evocative intermedial reference. If other cherubified titles tend to mix up different titles into a single world, Monster Hunter Stories wraps up the monsters from the other series of Monster Hunter. The monsters adapted from the source Monster Hunter are redesigned in a light tone to befit the target players of the game which are younger gamers. In the original games, the players hunt down monsters, slay them, skin them, and make weapons and armors out of their body parts. On the other hand, in this cherubified game, the players hatch a monster egg, breed the monster, befriend the monster, and ride it for an adventure. These changes indicate that conceptual modification takes place in the adaptation. This conceptual modification is realized by softening any words which are considered to be inappropriate for younger audiences.

These cherubification cases also further suggest the presence of a phenomenon known as crossover, where different characters from different titles are packed in a single universe. Crossovers not only emerge in games but also films and comics. Studio Puyukai's Isekai Quartet, taken from the word isekai which literally means 'world' but literarily means 'crossing the world', brings together the main characters from four famous anime titles into an alternate world. In relation to ludic adaptation, it further implies that cherubification, due to its condensed narratives and evocative intermedial references, generates a new experience from the users.

\section{DISCUSSION}

\section{THE PROBLEMS OF LUDIC IN THE STRUCTURE OF LUDIC ADAPTATION}

The word ludic is derived from ludus, which Caillois (2001) defines as a structured play with paidia being its opposite, denoting a spontaneous play. This definition implies that playful activities in ludus are procedurally structured, further implying that playfulness is structurally devisable. Ludic adaptation, holding on to the structural nature of ludus, is constructed by three intrinsic elements. Drawing upon Genette's hypertext, these intrinsic elements comprise of transmodalization, transstylization, and transformation. Problems arise on whether these elements possess playfulness as a structure which carries ludic values.

Transmodalization in the context of adaptation refers to how adaptation might shift the modes or functions of the originals. In the perspectives of text simplification, transmodalization revolves around conceptual modification. Since the domain lies on the concept, the ludic 
markers of any babyfied, chibified, bambified, and cherubified literary texts tend to start from the titles. The ludic markers, based on the findings, tend to circumnavigate around the use of diminutives. If we are to take radial category of diminutives as proposed by Jurafsky (1996), we might classify the diminutives which are functioned as a ludic marker in ludic adaptation as follows:

TABLE 8. Diminutive Mechanism

\begin{tabular}{ccc}
\hline Metaphor & $\begin{array}{c}\text { Diminutive Mechanism } \\
\text { Inference }\end{array}$ & Generalization \\
\hline Wan! & Baby & Pals \\
Oh! & Babies & Tales \\
Offline & Jr. & World \\
Stories & Junior & \\
& Kids & \\
& Koma & \\
& Mini & \\
& Pocket & \\
& Super Deformed & \\
& Young & \\
\hline
\end{tabular}

Metaphoric diminutive mechanism deals with the shift of meaning to a new domain, inferential with meaning which triggers the listeners or readers to infer something, and generalizational with the shifting of sense into new and less informative meaning (Jurafsky, 1996). In relation to ludic markers which denote that particular literary texts are intended for younger audiences and wrapped in text simplification, are dominantly delivered by inferential diminutive mechanism. As seen from table 8, babyfication and bambification tend to make use of this diminutive mechanism e.g Disney Babies and Young Donald Duck. On the other hand, ludic markers, which indicate that the adaptation emphasizes on the chibi visualization, are delivered through metaphoric and generalizational diminutive mechanism. Due to its emphasis on visualization, textual aspects tend to be expressively not informatively articulated. Therefore, metaphoric and generalizational mechanisms tend to occur on chibification and cherubification e.g. Monster Hunter Stories and World of Final Fantasy.

Diminutives, though fundamentally textual, are applicable also for visual and operative elements if the concept of being small, light, and easy is the entailment of diminutives. Super deformed or chibi animation style might fall into visual diminutives and simplified operation in accessing an app or playing a game might be considered as operative diminutives. That textual, visual, and operative aspects of a literary product are connected by diminutives indicates that ludic adaptation has a distinctive style which differentiates it from the other adaptation types. In ludic adaptation, since the target users are younger audiences, a shift on style related elements namely textual, visual, and operative adjustments is necessary. In YouTube Kids, for instance, the interface menu is simplified to adjust younger audiences. The simplification is perceivable from the condensation of video selection menu. The videos are only divided into recommended, shows, music, and an addition of learning media, which is not existent in the source text. The textual elements of the video selection are wrapped with visual beautification in the form of font types and icons, YouTube Kids attempts to align itself to the playful nature of kids. Recommended is visualized with heart icon, shows with popcorn, music with tone, learning with lamp, and explore with road signs. These visualizations are personified and displayed in a gif like animation to entice an attractive and interactive nuance, which might draw, notify, and lead the young users to interact with them. This condensation of video selection menu also indicates that operative elements are also simplified for an easy mechanical interaction. This example from YouTube Kids signifies the roles of textual, visual, and operative diminutives as a ludic marker of the app since the three elements are conceptually 
modified to evoke a playful nuance for younger audiences. This shift of style or what Genette (1997) calls as transstylization is important since styles to some extent define the text. Though an adaptation might have a different style from its source text, intertextual relationship between thesource text and the adaptation has to be taken into concern. Genette (1997) puts this concern on his idea about transformation.

Textual, visual, and operative diminutives which play a significant role in generating the ludicity of an adaptation not only define the style of ludic adaptation but also the source texts. The way these three diminutives define the source texts are through the preservation of core narratives or intermedial references. In transformation perspectives, diminutives are related to what Genette (1997) calls as excision, concision, and condensation. A hypertext intended for young audiences suffers one of these three types in relation to its hypotext. First, the hypertext might suffer from the cutting of irrelevant, irregular, or superfluous parts, which are considered to confuse, bore, or distract young audiences. This cutting is called excision. The interface menu of YouTube Kids, for instance, is the result of an excision since some items from its hypotext are not found. Excision through trimming is also exercised in a censorship manner to maintain moral lessons though it distorts the values of the hypotext. This censorship is termed expurgation. Bloody scenes and sexual attraction of the characters as found from Taira's Naruto: Rock Lee and His Ninja Pals, Taira's Chibi Sasuke's Sharingan Legend, Mashima's Fairy Tail S: Tales from Fairy Tail, Maruyama and So-bin's Overlord: The Undead King Kafka and Neko's Bungou Stray Dogs Wan! are down toned to adjust to the young audiences while attempting to align the narrative or the nuance of the hypotext. Second, the hypertext might suffer from rewriting aimed at generating an alternate narrative, from which younger audiences might find a new experience in enjoying it. This rewriting is called concision. DC Comics' Teen Titans Go!, the ludic adaptation of Teen Titans, for example, holds the core values, themes, and messages of the source text but wrapped in a new narrative and visualization, making the adaptation seem to be a product of rewriting. The last, a hypertext might suffer from a wrap up, where titles are collected in a single issue, sacrificing a heavy number of the narratives. This wrap up is called condensation. DC Comics' Scribblenauts Unmasked: a Crisis of Imagination, holding on the core theme and values of 5th Cell's Scribblenauts as a pedagogical media and DC Comics' Justice League as a save-the-worldfrom-certain-doom theme, the two titles are blended into a single title. Isekai Quartet, World of Final Fantasy, Super Gem Mini Mix/Pocket Fighter and Baby Looney Tunes fit also to this fourth transformation. Besides preserving the core narratives, the three diminutives which indicate the presence of ludic markers, as seen from table 1 and 8 , signify the source texts through intermedial references.

In the case of intermedial reference, Rajewsky (2011) implies that two possible types are present namely imitation and evocation. Imitation refers to a direct reference a hypertext has to the mediality of the hypotext while evocation to an indirect reference. The intermedial reference Final Fantasy XV: Pocket Edition and Tom and Jerry kids employ, for example, is imitative since they directly adopt the same mediality in terms of game mechanics for the former and the same media format for the latter. Intermedial reference is complementarily related to condensation with the former circumnavigating on the medial related aspects while the latter on the narrative or storial related aspects. Thus, as seen from findings, if the adaptations employ evocative intermedial references, they tend to adopt condensation and vice versa. In tandem with transmodalization and transstylization, these elements of transformation generate a playful communication.

Playful communication as the objective of ludic adaptation leaves a fundamental and philosophical problem on what defines playful in communication. Huizinga (2014) states that poiesis, the acts of making something into being, is a play-function. In the context of communication, what is planned to utter, what is uttered, and what is implied from the utterance 
are the acts of making communication and thereby, as implied by Huizinga (2014), they are poiesis in nature. Due to this poietic nature, communication is assumed to have a play-function, implying that they have play elements within them. Those play elements as implied by Huizinga (2014) comprise participants, rules of the game, goals, and prizes. The participants, in communication context, refer to who is involved in the communication, rules of the game to how the communication is carried out, goals to why the communication is done, and prizes to what the speakers might benefit from the communication. This play-function communication has is more apparent when the communication mood is that of play-mood, where lability and merriness are the key issues (Huizinga, 2014). These dual key issues are the focus of the playful communication in ludic adaptation since mood is embodied within each play element of a communication.

Huizinga (2014) implies that lability deals with how rules are broken to evoke playfulness. In ludic adaptation context, this lability is mostly seen in ludic adaptation aiming at evoking comedic tone. On the other hand, merrines as implied by Huizinga (2014) in the case of laetis animis canvivium peragunt (then they bring the banquet to a merry end) involves an exchange of taunting and humor delivered in a contest or a festive, engaged by a crowd of people. This concept of merriness is widely found in ludic adaptation, which focuses on crossover. In this genre, characters from different titles are brought into the same narratives, into which comedy and humour are applied. In Capcom's Pocket Fighter, for instance, famous characters from Capcom's fighting games are brought together to brawl in a single universe. They are pitted to best each other through fighting with taunting holding a significant role in the fight and narratives. Though the narratives of the game seem to be merry, the way the game is played requires seriousness. This seriousness is what is implied from the aforementioned case where contests and festives are the elements of merriness. Thus, to be merry, ones might need to be serious.

\section{CONCLUSION}

To indicate whether an adaptation falls into the category of ludic adaptation or not, ones can textually investigate the presence of ludic markers. The ludic markers revolve around the use of diminutives, derivational words which indicate size shifting from big to small. Diminutives like baby, kids, junior and other words signifying the state of being small tend to be affixed into the titles and the onomastic elements of the adapted texts. These diminutives function differently for each type of ludic adaptation. Babyfication and bambification tend to have inferential diminutives, which imply that text simplification with pedagogical purposes tends to be the main objective. On the other hand, chibification and cherubification tend to have metaphoric and generalizing diminutives, which indicate that they primarily lean over the chibi visualization and comedic narratives.

Diminutives, if seen from a larger scope, is the core of text simplification in a sense that babyfied, chibified, bambified, and cherubified ergodic texts are the 'small' version of their source texts. Trimming and pruning as proposed by Genette (1997) and text simplification by Siddharthan (2014) share the same philosophical concepts of diminutives, where source texts are cut to fit for a consumption by younger audiences. This focus on fitting a text for younger audiences, which is in line with ergodic literature that emphasizes on text accesibility for different users (Aarseth, 1997), further implies that diminutives are not just textually implemented but also visually and operatively. Visual and operative diminutives might refer to how the visual and operative elements of ergodic texts are made into a 'smaller' version through transmodalization, transstylization, and transformation. This diminution of textual, visual, and operative elements of an ergodic text to serve younger audiences is the core of ludic adaptation. 


\section{REFERENCES}

Aarseth, E. J. (1997). Cybertext: Perspectives on ergodic literature. Johns Hopkins University Press.

Caillois, R. (2001). Man, play, and games. University of Illinois Press.

De Belder, J., \& Moens, M.-F. (2010). Text simplification for children. Proceedings of the SIGIR Workshop on Accessible Search Systems, 19-26.

García Berrio, A. (2016). A Theory of the Literary Text. De Gruyter, Inc.

Genette, G. (1997). Palimpsests: Literature in the second degree. University of Nebraska Press.

Huizinga, J. (2014). Homo ludens: A study of the play-element in culture. Martino Fine Books. Jurafsky, D. (1996). Universal tendencies in the semantics of the diminutive. Language, 533578.

Mäyrä, F. (2012). Playful mobile communication: Services supporting the culture of play. Interactions: Studies in Communication \& Culture. 3(1), 55-70. https://doi.org/10.1386/iscc.3.1.55_1

Kacsuk, Z. (2018, September). Re-Examining the "What is Manga" Problematic: The Tension and Interrelationship between the "Style" Versus "Made in Japan" Positions. In Arts (Vol. 7, No. 3, p. 26). Multidisciplinary Digital Publishing Institute.

Nikolajeva, M. (2010). Interpretative codes and implied readers of children's picturebooks. In New directions in picturebook research (pp. 45-58). Routledge.

Petrucci, P. (2012). The translation of cinematic discourse and the question of character equivalence in Talk to me. Multilingua, 31(2-3). https://doi.org/10.1515/multi-20120011

Purnomo, SF. L. A., Nababan, M., Santosa, R., \& Kristina, D. (2017). Ludic Linguistics: A Revisited Taxonomy of Fictional Constructed Language Design Approach for Video Games. GEMA Online ${ }^{\circledR}$ Journal of Language Studies, 17(4), 45-60. https://doi.org/10.17576/gema-2017-1704-04

Purnomo, SF. L. A., Purnama, SF. L. S., Untari, L., Asiyah, N., \& Anggraini, N. (2019). Gamemunication: Prosthetic Communication Ethnography of Game Avatars. Jurnal Komunikasi: Malaysian Journal of Communication, 35(4), 1-16. https://doi.org/10.17576/JKMJC-2019-3504-01

Purnomo, SF. L. A., Untari, L., Purnama, SF. L. S., Asiyah, N., Muttaqien, M. Z., Umam, R. K., Sartika, Y., Pujiyanti, U., \& Nurjanah, H. (2020). King size or all size: Proposing a typology of amplification translation technique for children picturebook translation. Studies in English Language and Education, 7(2), 558-575. https://doi.org/10.24815/siele.v7i2.16592

Rajewsky, I. O. (2011). Intermediality, Intertextuality, and Remediation: A Literary Perspective on Intermediality. Intermédialités, 6, 43-64. https://doi.org/10.7202/1005505ar

Sanders, J. (2005). Adaptation and appropriation. Routledge.

Siddharthan, A. (2006). Syntactic Simplification and Text Cohesion. Research on Language and Computation, 4(1), 77-109. https://doi.org/10.1007/s11168-006-9011-1

Siddharthan, A. (2014). A survey of research on text simplification. ITL - International Journal of Applied Linguistics, 165(2), 259-298. https://doi.org/10.1075/itl.165.2.06sid

Spradley, J. P. (2016). Participant observation. Waveland Press.

Yaneva, V. (2015). Easy-read Documents as a Gold Standard for Evaluation of Text Simplification Output. Proceedings of the Student Research Workshop Associated with RANLP 2015, 30-36. 


\section{SOURCES}

APP SOURCES

http://www.nickjr.tv/

https://disneynow.com/all-shows/disney-junior

https://pbskids.org/

https://www.hbo.com/kids

https://www.hulu.com/hub/kids

https://www.youtubekids.com/

COMIC AND LIGHT NOVEL SOURCES

Akatsuki, N., \& Mishima, K. (2019). Konosuba: God's blessing on this wonderful world!. 10, 10, (K. Steinbach, Trans.). Yen On.

Artibani, F., Ambrosio, S., Ferrari, A., Intini, S., Mazzarello, M., Dalena, A., D’Ippolito, F., \& Long, T. B. (2019). Young Donald Duck. Jeremy Ratt Boarding School. IDW Publishing.

Asagiri, K., \& Harukawa, S. (2016). Bungo stray dogs (K. Gifford \& B. Pistillo, Trans.; First Yen Press edition). Yen Press.

Atsushi, O. (2012). Let's Start [Koma-Bleach]. Jump Comics.

Butts, L. (1987). Disney Babies: Baby Donald Makes a Sandwich: a Book about Sequencing. The Walt Disney Company. Company.

Elder, J., Archer, A., Bates, B., \& Herring, I. (2014). Scribblenauts Unmasked: A Crisis of Imagination (Vol. 1). DC Comics.

Gould, R. D. (1987). Disney Babies at the Big Circus: a Book of Opposites. The Walt Disney Company.

Hardy, A. D. (1987). Disney Babies: Baby Goofy Catches a Fish. A Book About RhymingWords. Grolier Books.

Hardy, A. D. (1987). Disney Babies: Where's Baby Mickey's Red Ball: A Book about Colors. The Walt Disney Company.

Hardy, A. D. (1990). Disney Babies: Good Night, Baby Donald: A Book about Counting. The Walt Disney Company.

Isayama, H. (2012). Attack on Titan (S. Drzka \& S. Wands, Trans.; Vol. 1). Kodansha Comics.

Johns, G., Kindt, M., Lemire, J., Finch, D., Booth, B., \& Mahnke, D. (2013). Justice League of America. Vol 1, Vol 1,. DC Comics

Kawahara, R., \& Nakamura, T. (2014). Sword Art Online: Aincrad (S. Paul \& Albuquerque Business Education Compact, Trans.). Yen Press.

Kishimoto, M. (2003). Naruto (J. Duffy, A. Kirsch, \& M. Morimoto, Trans.; Shonen Jump manga edition). Viz Media.

Kubo, T. (2004). Bleach (L. Caselman \& J. Yamazaki, Trans.; Shonen jump manga edition). Viz Media.

Lakin, P. (1990). Disney Babies at the Farm: a Book about Farm Words. The Walt Disney

Maruyama, K. \& Oshio, S. (2016). Overlord: the Undead King Oh!. Yen Press.

Maruyama, K. \& So-bin. (2016). Overlord. Volume 1, Volume 1, (E. Balistrieri, Trans.). Yen Press.

Mashima, H. (2008). Fairy tail (W. Flanagan, Trans.). Del Rey/Ballantine Books

Mashima, H. (2017). Fairy Tale S: Tales from fairy tail (W. Flanagan, Trans.). Kodansha Comics.

Nagatsuki, T., Otsuka, S., \& ZephyrRz. (2016). Re:ZERO starting life in another world (J. Bourque, Trans.; First Yen On edition). Yen On. 
Nakagawa, S., \& Isayama, H. (2014). Attack on Titan: Junior high (W. Flanagan, Trans.). Kodansha Comics, an imprint of Kodansha USA Publishing, LLC.

Neko, K. (2016). Bungou Stray Dogs Wan!. Kadokawa.

Phillips, J., \& Disney, W. (1970). Walt Disney's Donald Duck's circus. Purnell.

Taira, K. \& Kishimoto, M. (2010). Rock Lee's Springtime of Youth Full-Power Ninja Chronicles. Saikyo Jump.

Taira, K., \& Kishimoto, M. (2014). Naruto. Chibi Sasuke's sharingan legend (A. Haley, T. Willis, \& S. Aharon, Trans.; Shonen Jump manga edition). Viz Media LLC.

Van Horn, W., Leach, G., Lustig, J., Daigle-Leach, S., \& Struzan, D. (Eds.). (2018). DuckTales classics. IDW Publishing.

Waid, M., Pérez, G., Ordway, J., \& Kolins, S. (2008). The brave and the bold. DC Comics.

Zen, C., \& Shinotsuki, S. (2017). The saga of Tanya the evil (E. Balistrieri \& K. Steinbach, Trans.; First Yen On edition). Yen On.

\section{ANIMATED FILM SOURCES}

Araki, T. (2013). Attack on Titan. [Dark Fantasy]. Funimation.

Ashina, M. (2019). Isekai Quartet. [Comedy Isekai]. Studio Puyukai.

Avery, T. (1987). Looney Tunes. [Comedy]. Warner Bros. Animation.

Date, H. (2002). Naruto. [Adventure]. Animax.

Davis, A. (1988). The Flintstone Kids. [Comedy]. Hanna-Barbera Productions.

Gatrall, J., Hack, M., \& Heming, S. (2001). Baby Looney Tunes [Comedy]. Warner Bros. Television.

Hanna, W., \& Barbera, J. (1957). Tom and Jerry [Comedy]. MGM Cartoons.

Hanna, W., \& Barbera, J. (1960). The Flintstones [Comedy]. Hanna-Barbera Productions.

Hanna, W., \& Barbera. J. (1990). Tom \& Jerry Kids [Comedy]. Turner Entertainment.

Ibata, Y. (2015). Attack on Titan: Junior High. [Comedy]. Aniplus Asia.

Ito, T. (2012). Sword Art Online. [Adventure]. Aniplex Channel.

Jackson, Wilfred. (1934). The Wise Little Hen. [Comedy]. Walt Disney Productions.

Jelenic, M., \& Horvath, A. (2013). Teen Titans Go! [Adventure]. Warner Bros. Television Distribution.

Lusk, Don. (1991). A Pup Named Scooby-Doo. [Horror Comedy]. Hanna-Barbera Productions.

Murata, M. (2012). Naruto Spin-Off: Rock Lee \& His Ninja Pals. [Comedy]. Viz Media.

Ruby, J. \& Spears, K. (1976). Scooby-Doo, Where are You! [Horror Comedy]. HannaBarbera Productions.

Sharpsteen, B. (1936). Mickey's Circus. [Comedy]. Metro-Goldwyn-Mayer.

Sharpteen, B., Ferguson, N., Jackson, W., Roberts, B., Kinney, J., \& Armstrong, S. (1941). Dumbo. RKO Radio Pictures.

\section{VIDEO GAME SOURCES}

Final Fantasy Anthology (Playstation version) [Video Game]. (2002). Tokyo, Japan: Square. Final Fantasy III Remake (Nintendo DS version) [Video Game]. (2006). Tokyo, Japan: Square Enix.

Final Fantasy IV Remake (Nintendo DS version) [Video Game]. (2008). Tokyo, Japan: Square Enix.

Final Fantasy IX (Playstation version). [Video Game]. (2000). Tokyo, Japan: Square Electronic Arts.

Final Fantasy Origins (Playstation version) [Video Game]. (2003). Tokyo, Japan: Square. 
Final Fantasy VII Remake (Playstation 4 version) [Video Game]. (2020). Tokyo, Japan: Square Enix.

Final Fantasy VIII (Playstation version). [Video Game]. (1999). Tokyo, Japan: Square.

Final Fantasy X (Playstation 2 version). [Video Game]. (2002). Tokyo, Japan: Square Electronic Arts.

Final Fantasy X-2 (Playstation 2 version). [Video Game]. (2003). Tokyo, Japan: Square Electronic Arts.

Final Fantasy XII (Playstation 2 version). [Video Game]. (2006). Tokyo, Japan: Square Enix. Final Fantasy XIII (Playstation 3 version). [Video Game]. (2010). Tokyo, Japan: Square Enix. Final Fantasy XIII-2 (Playstation 3 version). [Video Game]. (2012). Tokyo, Japan: Square Enix.

Final Fantasy XV (Playstation 4 version). [Video Game]. (2016). Tokyo, Japan: Square Enix. Final Fantasy XV: Pocket Edition (Android version). [Video Game]. (2018). Tokyo, Japan: Square Enix.

Lightning Returns: Final Fantasy XIII (Playstation 3 version). [Video Game]. (2014). Tokyo, Japan: Square Enix.

Minecraft: Pocket Edition (Android version). [Video Game]. (2015). Stockholm, Sweden: Mojang Studios

Monster Hunter (Playstation 2 version). [Video Game]. (2004). Tokyo, Japan: Capcom.

Monster Hunter Stories (Android version). [Video Game]. (2018). Tokyo Japan: Capcom.

Pocket Fighter (Playstation version). [Video Game]. (2006). Tokyo, Japan: Capcom.

Street Fighter Alpha 3 (Playstation version). [Video Game]. (1998). Tokyo, Japan: Capcom.

Street Fighter II (NES version), [Video Game]. (1992). Tokyo, Japan: Capcom.

Theatrhythm Final Fantasy (Nintendo 3D version). [Video Game]. (2012). Tokyo, Japan: Square Enix.

World of Final Fantasy (Playstation 4 version). [Video Game]. (2016). Tokyo, Japan: Square Enix.

\section{ABOUT THE AUTHORS}

SF. Luthfie Arguby Purnomo holds a doctoral degree in linguistics. His research revolves around perceiving computer games from language perspectives. His works were published by internationally and nationally accredited journals. He is currently teaching at English Letters at the State Islamic Institute of Surakarta, Indonesia.

Lilik Untari holds a doctoral degree in translation studies. Her interests circumnavigate around children literature translation which spans from the translation of children picturebook to computer games. She is currently teaching at English Letters and the Graduate School at the State Islamic Institute of Surakarta, Indonesia.

SF. Lukfianka Sanjaya Purnama holds a master degree in international communication and linguistics. Besides teaching at English Letters at the State Islamic Institute of Surakarta, Indonesia, he helms I After Smile game studio as a CEO. His research deals with game studies. His games focus mainly on mobile and PC.

Nur Asiyah is a doctoral candidate in American Studies. Her research interests are children, diasporic, and post colonial literature in the context of American Studies. She is currently helming English Letters at the State Islamic Institute of Surakarta, Indonesia, as the head of the study program. 
Robith Khoiril Umam holds a master degree in linguistics. He finds interests in the implementation of systemic functional linguistics for various purposes. He is currently teaching at English Letters at the State Islamic Institute of Surakarta, Indonesia.

Yustin Sartika holds a master degree in American Studies. Her research deals with popular culture, film studies, and culinary literature. She is currently teaching at English Letters at the State Islamic Institute of Surakarta, Indonesia.

Novianni Anggraini is a doctoral candidate in Islamic education management with the focus on elementary education. She is interested in website management for pedagogical purposes. She is currently teaching at English Language Education at the State Islamic Institute of Surakarta, Indonesia.

Elen Inderasari is a doctoral candidate in Islamic education management with the focus on character development. Her research focuses on literature education in Indonesian literature context. She is currently teaching at Indonesian Language Education at the State Islamic Institute of Surakarta, Indonesia. 